\title{
PEMANFAATAN TUNJANGAN PROFESI PENDIDIK BAGI GURU-GURU SMA DI KOTA BANJARMASIN
}

\author{
Santi Mulya Dewi ${ }^{1}$, Suratno2 ${ }^{2}$, Mahmudah Hasanah ${ }^{3}$ \\ santimulyadewi193@gmail.com; ontar_ria@ulm.ac.id; hasanah.mahmudah@gmail.com \\ Program Studi Pendidikan Ekonomi Jurusan Pendidikan IPS \\ Fakultas Keguruan dan Ilmu Pendidikan \\ Universitas Lambung Mangkurat, Banjarmasin
}

\begin{abstract}
ABSTRAK:
Penelitian ini bertujuan mengetahui pemanfaatan tunjangan profesi pendidik bagi guru-guru dan menguji perbedaannya berdasarkan karakteristik guru menurut jenis kelamin, lama menikmati tunjangan, jumlah tanggungan keluarga, dan masa kerja.Teknik pengumpulan data yang digunakan adalah angket dengan responden sebanyak 105 guru SMA di Kota Banjarmasin. Penelitian ini menggunakan pendekatan kuantitatif dengan metode deskriptif komparatif. Hasil penelitian menunjukan bahwa pemanfaatan tunjangan profesitermasuk dalam kategori cukup baik diakui oleh 68 guru $(64,8 \%)$ dari 105guru.Pemanfaatan tunjangan profesi pendidik untuk peningkatan dan pengembangan profesi termasuk kategori cukup baik dialami oleh 55 guru $(52,4 \%)$ dan termasuk kategori cukup baik untuk pengeluaran keluarga atau rumah tangga dialami oleh 49 guru $(46,7 \%)$. Tidak ditemukan perbedaan pemanfaatan tunjangan profesi pendidik berdasarkan jenis kelamin dengan nilai tosebesar 0,097 dengan $\mathrm{p}>0,05$. Tidak ditemukanperbedaan pemanfaatan tunjangan profesi pendidik berdasarkan lama menikmati tunjangan yaitu lama, sedang, dan baru ( $F=2,202: p$ $>0,05$ ). Tidak ditemukan perbedaan pemanfaatan tunjangan profesi pendidik berdasarkan jumlah tanggungan, yaitu sedikit, sedang, dan banyak ( $F=2,520: p>0,05)$. Ditemukan perbedaan pemanfaatan tunjangan profesi pendidik berdasarkan masa kerja, yaitu baru, sedang, dan lama ( $\mathrm{F}=$ $4,486: \mathrm{p}<0,05)$. Para guru sudah cukup baik dalam mengalokasikan tunjangan profesi pendidik untuk peningkatan dan pengembangan profesi maupun pengeluaran keluarga atau rumah tangga. Tidak ditemukan perbedaan pemanfaatan tunjangan profesi pendidik berdasarkan jenis kelamin, lama menikmati tunjangan, dan jumlah tanggungan keluarga; akan tetapi ditemukan perbedaan yangsignifikan pemanfaatan tunjangan profesi pendidik berdasarkan masa kerja guru.
\end{abstract}

Kata kunci : tunjangan profesi, pemanfaatan, guru.

\begin{abstract}
:
This study aims to determine the use of professional teacher allowances for teachers, and to test of the differences based on the characteristics of teachers according to sex, length of enjoying benefits, number of family dependents, and years of service. Data collection techniques used were questionnaires with respondents as many as 105 high school teachers in Banjarmasin. This research uses a quantitative approach with comparative descriptive methods. The results showed that the utilization of professional allowances included in the quite good category was recognized by 68 teachers $(64.8 \%)$ of 105 teachers. The utilization of professional allowances for educators for professional development and development is quite good for 55 teachers $(52.4 \%)$ and quite good for family or household expenses experienced by 49 teachers $(46.7 \%)$. There were no differences in the utilization of professional allowances for educators based on gender with a t0 value of 0.097 with $p>$ 0.05 . No difference was found in the use of the professional allowance for educators based on how long they enjoyed benefits, namely old, medium and new $(F=2.202: p>0.05)$. No difference was found in the use of the professional allowance for educators based on the number of dependents, namely few, medium, and many $(F=2.520: p>0.05)$. Found differences in the use of professional allowances for educators based on years of service, namely new, moderate and old ( $F=4.486: \mathrm{p}$ $<0.05)$. The teachers are good enough in allocating professional allowances for educators to increase and develop the profession and family or household expenses. No differences were found in the use
\end{abstract}


of professional allowances for educators based on sex, duration of benefits, and number of family dependents; however, a significant difference was found in the utilization of the professional allowance of the educator based on the teacher's tenure.

Keywords: professional allowance, utilization, teacher.

\section{Pendahuluan}

Pemerintah melalui Menteri Pendidikan Nasional Republik Indonesia telah memberlakukan Peraturan Menteri No 18 Tahun 2007 tentang Sertifikasi Bagi Guru secara Nasional. Program ini bertujuan untuk meningkatkan mutu pendidikan nasional, dengan diimbangipemberian tunjangan profesi pendidik. Tunjangan tersebut besarnya sama dengan satu kali gaji pokok sehingga otomatis meningkatkan pendapatan guru.

Pada dasarnya, Pemerintah memberikan tunjangan profesi guru untuk meningkatkan profesional guru sehingga mutu pendidikan tercapai. Akan tetapi, banyak guru salah paham terhadap tujuan program sertifikasi karena pemberian tunjangan profesi pendidik, seakan-akan tujuan utama dari sertifikasi adalah tunjangan profesi pendidik. Hal tersebut terbukti dengan hasil penelitian di Surakarta, yang menyatakan tunjangan profesi pendidik digunakan untuk membeli kebutuhan pribadi yang berakibat pada pola konsumtif (Rochani, Haryono, dan Budiati, 2012). Mirisnya, sebagaimana yang dikemukakan oleh Muhammad Ramli Rahim, Ketua Umum Ikatan Guru (IGI) (Banjarmasinpost.co.id,2016) bahwa hanya empat persen saja di antaranya yang menggunakan tunjangan bernama sertifikasi itu untuk kepentingan peningkatan kompetensi guru dalam mengajar. Bahkan kualitas guru di Indonesia dinilai mengalami kemunduran setelah adanya kebijakan tunjangan sertifikasi. Selain itu, setelah mendapatkan tunjangan profesi pendidik, kompetensi profesional guru tetap sama dan belum menunjukan upaya peningkatan penguasaaan kompetensi profesional (Murdadi dan Sulistari, 2015).

Penelitian-penelitian sebelumnya menjelaskan bagaimana peningkatan pendapatan akibat tunjangan profesi pendidik mempengaruhi pola konsumsi dan kinerja guru. Selain mempengaruhi konsumsi, tentu akan mempengaruhi pengeluaran lainnya, seperti tabungan, investasi, dan liburan. Kejadian fenomenal lainnya yaitu 
maraknya perceraian yang dilakukan oleh wanita karena merasa tidak selevel dengan profesi suami karena ketimpangan pendapatan (Harianjogja.com, 2015). Pada dasarnya, tunjangan profesi pendidik harus untuk meningkatkan profesional guru misalnya mengikuti seminar dan pelatihan serta membeli buku, dan lain-lain.

Kasus lain ditemukan, bahwa di Banjarbaru, kenaikan pendapatan guru bersertifikat tidak berpengaruh positif terhadap peningkatan profesional guru Bahasa Inggris. Kesadaran akan kinerja guru setelah peningkatan pendapatan dari sertifikasi guru relatif tidak memuaskan. Hal tersebut dikarenakan kinerja guru terhadap pendidikan dan pelatihan serta pembelian buku pelengkap untuk perkembangan kapasitas tidak memuaskan (Rina Listia, Fatchul, dan Moh. Yamin, 2013).

Fenomena lainnya yang terjadi yaitu berdasarkan nilai Uji Kompetensi Guru dari Lembaga Penjamin Mutu Pendidikan Kalimantan Selatan dapat dilihat nilai kompetensi profesional guru-guru SMA kurang baik dengan nilai terendah 53, sehingga perlu adanya tinjauan pemanfaatan tunjangan profesi pendidik oleh guruguru. Adapun jumlah guru bersertifikasi di Kota Banjarmasin sebagai berikut :

Tabel 1. Jumlah Penerima Tunjangan Profesi Guru Jenjang SMA Semester 1 Tahun Anggaran 2017 di Kota Banjarmasin

\begin{tabular}{|c|c|c|c|}
\hline \multirow{2}{*}{$\begin{array}{l}\text { Status } \\
\text { Sekolah }\end{array}$} & \multicolumn{2}{|c|}{ Jenis kelamin } & \multirow[b]{2}{*}{$\mathrm{Jml}$} \\
\hline & $\begin{array}{l}\text { Laki- } \\
\text { laki }\end{array}$ & $\begin{array}{c}\text { Perempua } \\
\mathrm{n}\end{array}$ & \\
\hline Negeri & 136 & 237 & 373 \\
\hline Swasta & 12 & 16 & 28 \\
\hline Jumlah & 148 & 253 & 401 \\
\hline
\end{tabular}

Sumber:Dinas Pendidikan dan Kebudayaan Prov. Kalimantan Selatan, 2017.

Tabel 2. Perkembangan Jumlah Kelulusan Peserta Sertifikasi Guru Kota Banjarmasin $2007-2016$

\begin{tabular}{|c|r|r|r|}
\hline Tahun & \multicolumn{2}{|c|}{ Status Sekolah } & \multirow{2}{*}{ Jumlah } \\
\cline { 2 - 3 } Lulus & Negeri & Swasta & \\
\hline 2007 & 27 & 1 & 28 \\
\hline 2008 & 155 & 12 & 167 \\
\hline 2009 & 77 & 8 & 85 \\
\hline 2010 & 35 & 4 & 39 \\
\hline 2011 & 43 & 3 & 46 \\
\hline 2012 & 7 & 0 & 7 \\
\hline 2013 & 7 & 0 & 7 \\
\hline 2014 & 2 & 0 & 2 \\
\hline
\end{tabular}




\begin{tabular}{|c|r|r|r|}
\hline Tahun & \multicolumn{2}{|c|}{ Status Sekolah } & \multirow{2}{*}{ Jumlah } \\
\cline { 2 - 3 } Lulus & Negeri & Swasta & \\
\hline 2015 & 7 & 0 & 7 \\
\hline 2016 & 13 & 0 & 13 \\
\hline Jumlah & 373 & 28 & 401 \\
\hline
\end{tabular}

Sumber:Dinas Pendidikan dan Kebudayaan Prov. Kalimantan Selatan

Berdasarkan latar belakang masalah di atas dapat dirumuskan masalah yaitu:

1. Bagaimana gambaran umum dan tingkat pemanfaatan tunjangan profesi bagi guru-guru SMA di Kota Banjarmasin?

2. Apakah terdapat perbedaan pemanfaatan tunjangan profesi pendidik berdasarkan jenis kelamin, lama menikmati tunjangan,kategori jumlah tanggungan keluarga, dan kategori masa kerja?

Berdasarkan Undang-Undang Republik Indonesia Nomor 14 Tahun 2005 tentang Guru dan Dosen pasal 1 ayat 11, menyatakan bahwa sertifikasi adalah proses pemberian sertifikat pendidik, yang merupakan bukti formal sebagai pengakuan yang diberikan kepada guru dan dosen sebagai tenaga profesional.

Menurut Rasyid (2014: 433), sertifikasi dapat diartikan suatu proses pemberian pengakuan bahwa seseorang telah memiliki kompetensi untuk melaksanakan pelayanan pendidikan pada satuan pendidikan.

Berdasarkan pengertian tersebut dapat disimpulkan bahwa sertifikasi merupakan suatu proses untuk mendapatkan pengakuan sebagai tenaga profesional yang memiliki kompetensi untuk memberikan pelayanan dalam satuan pendidikan tertentu dibuktikan dengan sertifikat pendidik.

Berdasarkan Peraturan Menteri Negara Pendayagunaan Aparatur Negara dan Reformasi Birokrasi No 16 Tahun 2009 tentang jabatan fungsional guru dan angka kreditnya pasal 5, tugas utama guru adalah mendidik, mengajar, membimbing, mengarahkan, melatih, dan mengevaluasi peserta didik pada pendidikan anak usia dini jalur pendidikan formal, pendidikan dasar, dan pendidikan menengah serta tugas tambahan yang relevan dengan fungsi sekolah/madrasah.

Dalam melaksanakan tugas, guru berkewajiban : (a) merencanakan pembelajaran/bimbingan, melaksanakan pembelajaran/bimbingan yang bermutu, 
menilai dan mengevaluasi hasil pembelajaran/bimbingan, serta melaksanakan pembelajaran/perbaikan dan pengayaan. (b) meningkatkan dan mengembangkan kualifikasi akademik dan kompetensi secara berkelanjutan sejalan dengan perkembangan ilmu pengetahuan, teknologi, dan seni.

Rumah tangga terdiri dari satu atau lebih orang yang tinggal bersama-sama di sebuah tempat tinggal dan berbagi makanan atau akomodasi untuk hidup, dan bisa terdiri dari satu keluarga atau sekelompok orang'. (Setiowati, Nur Eka,2016 : 299) Rumah tangga adalah unit sosial yang tinggal di sebuah tempat tinggal. Umumnya, rumah tangga adalah sebuah keluarga. Keluarga adalah unit dasar organisasi sosial pada sebagian besar negara di dunia dan fokus utama konsumsi (Charles Doyle, 2011, terjemahan Hartati Widiastuti, 2013: 224)

Konsumsi rumah tangga keluarga adalah pengeluaran yang dilakukan untuk membeli berbagai jenis kebutuhan berupa barang dan jasa untuk memenuhi kebutuhan individu atau kelompok dalam keluarga.

Dari sifat sirkulasi aliran pendapatan yang terdapat dalam gambar itu dapat diambil kesimpulan bahwa aliran-aliran pendapatannya mempunyai ciri-ciri sebagai berikut

a. Sebagian besar pendapatan yang diterima rumah tangga akan digunakan untuk konsumsi, yaitu membeli barang-barang dan jasa yang dihasilkan oleh sektor perusahaan.

b. Sisa pendapatan rumah tangga yang tidak digunakan untuk konsumsi akan ditabung dalam instansi-instansi keuangan.

Beberapa pos pengeluaran dalam keuangan keluarga sebagai berikut :

a. Pos Biaya Hidup

Pos biaya hidup adalah pos untuk pemenuhan kehidupan sehari-hari seperti makan, biaya rumah ( sewa, listrik, dan air), ongkos transportasi untuk bekerja dab sekolah serta uang jajan anak.

b. Pos Kewajiban Finansial

Sebagai sebuah keluarga yang relatif muda, banyak yang masih terikat dengan cicilan 
rumah atau kendaraan. Hal ini bersama dengan hutang kartu kredit termasuk dalam pos kewajiban finansial yang pengeluarannya perlu diprioritaskan.

c. Pos Tabungan (Dana Darurat)

Fungsi utama pos ini adalah untuk digunakan mendadak seperti kehilangan pekerjaan, tapi ketika ada kebutuhan mendadak seperti adanya kebutuhan maintenance rumah, pos ini juga dapat difungsikan.

d. Pos Masa Depan

Pos masa depan adalah salah satu pos terpenting karena menyangkut masa depan keluarga. Di dalam pos ini ada kebutuhan investasi untuk pendidikan anak dan persiapan dana pensiun serta pemeblian asurasni sebagai alat proteksi diri dari resiko finansial.

e. Pos Sosial

Pos sosial merupakan salah satu pos yang sering terlupakan tetapi jika tidak disisihkan, dapat mengganggu pengeluaran rutin rumah tangga. Jumlah pengeluaarnnya memang tidak menentu, tetapi pos ini sangat berfungsi apabila tiba-tiba menghadiri ulang tahun teman anak sekolah, membayar arisan dan membantu keluarga yang sedang mengalami musibah.

f. Pos Lifestyle

Pos ini adalah pos di mana yang dialokasikan utuk melakukan hal-hal yang menyenangkan seperti nonton bersama keluarga, pergi ke salon atau liburan keluarga. Pos ini sebagai salah satu pos yang sifatnya wants dan bukan needs.

g. Pos Pengeluaran Rutin Tahunan

Hal yang termasuk pos ini adalah pajak tahunan seperti pajak bumi dan bangunan dan perpanjangan STNK kendaraan. Selain itu ada Qurban bagi umat muslim.

Hubungan Antara Konsumsi, Tabungan dan Pendapatan. Terdapat beberapa faktor yang menentukan tingkat pengeluaran rumah tangga, yang terpenting adalah pendapatan rumah tangga. Hubungan di antara tingkat pendapatan dengan pengeluaran konsumsi dan tabungan sebagai berikut :

a. Pada pendapatan yang rendah akan mengorek tabungan.

b. Kenaikan pendapatan menaikan pengeluaran konsumsi. 
c. Pada pendapatan yang tinggi rumah tangga menabung.

Teori Keynes

Teori Konsumsi keynes didasarkan pada 3 postulat yaitu :

a. Menurut hukum psikologis fundamental (katakanlah ia sebagai hukum keynes), bahwa konsumsi akan meningkat apabila pendapatan meningkat.

b. Setiap terjadi peningkatan pendapatan maka pastilah rata-rata kecenderungan menabung akan semakin tinggi.

c. Pendapatan adalah determinan (faktor penentu utama) dari konsumsi. Hukum Engel

Penelitian Engel melahirkan empat butir kesimpulan. Salah satu dari kesimpulan tersebut adalah jika pendapatan meningkat, maka persentase pengeluaran untuk pendidikan, kesehatan,rekreasi, barang mewah, dan tabungan semakin meningkat. Perilaku Konsumen

Perilaku konsumen adalah tindakan pengambilan keputusan oleh individu, kelompok bahkan organisasi dalam proses pengambilan keputusan pembelian demi memenuhi kebutuhan dan keinginan.

Faktor-faktor yang mempengaruhi perilaku konsumen yaitu faktor internal dan eksternal. Faktor internal terdiri dari motivasi, persepsi, proses belajar, dan kepercayaan dan sikap. Faktor eksternal terdiri dari :

a. Faktor kebudayaan yang mencakup kelas sosial,

b. faktor sosial yang mencakup kelompok referensi, keluarga, dan peran dan status,

c. faktor pribadi yang mencakup umur, pekerjaan, keadaan ekonomi, gaya hidup, kepbribadian dan konsep diri, jenis kelamin atau identitas kelami,

d. Pengaruh dinamika kelompok yang mencakup struktur keluarga dan rumah tangga yang berubah, peran wanita yang berubah, dan peranan pria yang berubah.

\section{METODE}

Penelitian ini menggunakan pendekatan kuantitatif dengan metode deskriptif dan komparatif. Metode deskriptif menggambarkan secara umum pemanfaatan tunjangan profesi pendidik dan metode komparatif untuk mengetahui membedaan 
penggunaan berdasarkan karakteristik responden yaitu jenis kelamin, status sekolah, lama menikmati tunjangan profesi pendidik, kategori jumlah tanggungan, dan kategori masa kerja. Adapun populasi penelitian ini yaitu guru-guru SMA yang mendapatkan tunjangan profesi pendidik semester satu tahun anggaran 2017 di Kota Banjarmasin.

Penentuan jumlah sampel dalam penelitian ini menggunakan rumus estimasi selang dengan populasi finit (diketahui) dengan taraf kesalahan 10\% sebanyak 78 responden. Kemudian sampel ditambah 1/3n yaitu sebanyak 26 responden. Sehingga sampel sebanyak 104 responden. Kemudian pengambilan proporsi sampel setiap kelasnya dihitung menggunakan rumus Proportionate Classter Random.

Secara rinci besar sampel dalam penelitian ini dapat dilihat melalui tabel berikut :

Tabel 3 Daftar Distribusi Sampel Penelitian

\begin{tabular}{|c|c|c|c|}
\hline No & $\begin{array}{c}\text { Status } \\
\text { Sekolah }\end{array}$ & $\begin{array}{c}\text { Populasi } \\
\text { Guru }\end{array}$ & $\begin{array}{c}\text { Sampel } \\
\text { Guru }\end{array}$ \\
\hline 1 & Negeri & 373 & 97 \\
\hline 2 & Swasta & 28 & 8 \\
\hline \multicolumn{2}{|c|}{ Jumlah } & 401 & 105 \\
\hline
\end{tabular}

Sumber : Data Primer, 2018

Berdasarkan perhitungan di atas sehingga sampel total dari penelitian ini yaitu 105 responden. Teknik untuk menentukan sampel menggunakan Simple Random Sampling. Pengumpulan data primer menggunakan kuesioner.

Kisi-kisi pernyataan dalam kuesioner terdiri atas satu variabel yaitu pemanfaatan tunjangan profesi pendidik dengan dua sub variabel yaitu pengeluaran untuk peningkatan dan pengembangan profesi dan pengeluaran konsumsi rumah tangga atau keluarga. Pada sub variabel pengeluaran untuk peningkatan dan pengembangan profesi terdiri atas pendidikan, pembelajaran/bimbingan dan tugas tertentu pengembangan keprofesian berkelanjutan, dan penunjang tugas tertentu, sedangkan pada sub variabel pengeluaran konsumsi rumah tangga atau keluarga terdiri atas biaya hidup, kewajiban finansial, tabungan, masa depan, sosial, lifestyle, dan rutin tahunan. 


\section{HASIL PENELITIAN DAN PEMBAHASAN}

Gambaran umum mengenai karakteristik responden yaitu jenis kelamin, status sekolah, lama menikmati tunjangan kategori jumlah tanggungan, dan kategori masa kerja sebagai berikut :

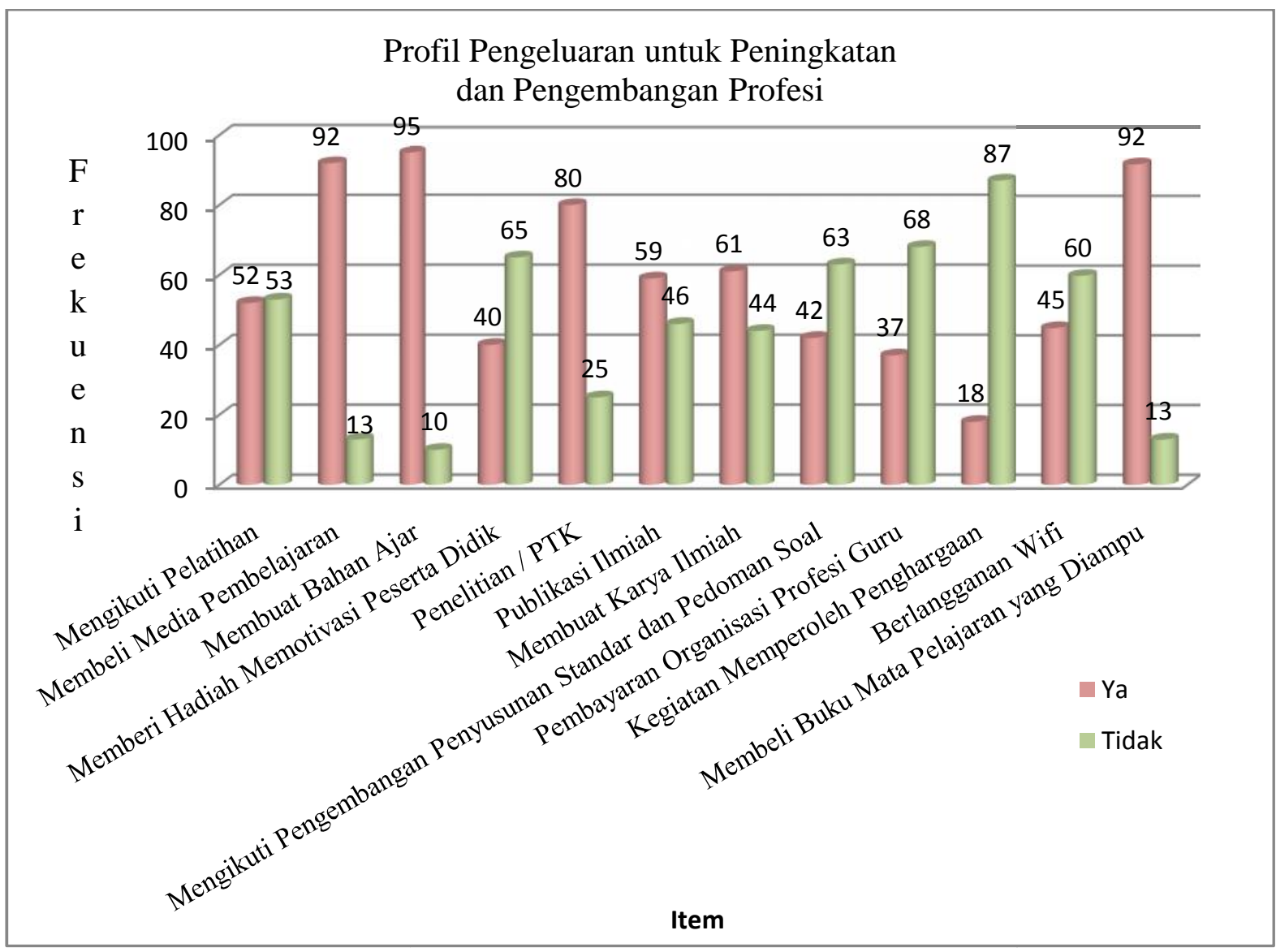

Grafik 1 : Profil Pengeluaran untuk Peningkatan dan Pengembangan Profesi

Berdasarkan grafik 1 di atas dapat diketahui bahwa guru-guru banyak menggunakan tunjangan profesi pendidik untuk membeli media pembelajaran, membuat bahan ajar, melakukan PTK dan membeli buku mata pelajaran yang diampu dengan berturut-turut sebanyak 93, 95, 80, dan 93 guru. Kemudian guruguru banyak yang tidak menggunakan tunjangan profesi pendidik untuk memberi hadiah, memotivasi peserta didik, mengikuti pengembangan penyusunan standart dan pedoman soal, dan kegiatan memperoleh penghargaan. 


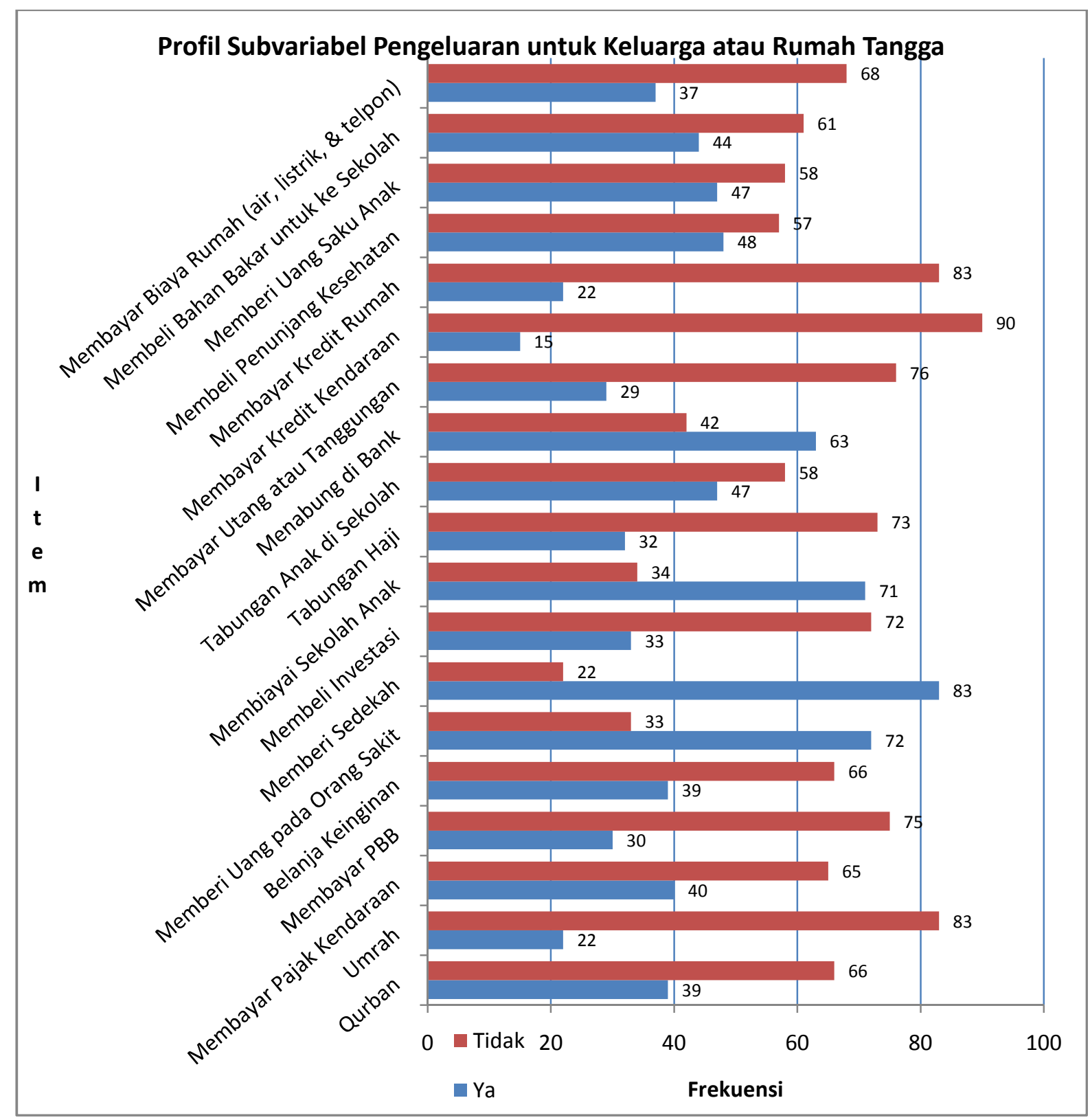

Grafik 2 : Profil Pengeluaran untuk Keluarga atau Rumah Tangga

Berdasarkan grafik 2 dapat diketahui bahwa pada subvariabel pengeluaran untuk keluarga atau rumah tangga, guru-guru banyak menggunakan tunjangan profesi pendidik untuk menabung di Bank, membiayai sekolah anak, memberi sedekah,dan memberi uang pada orang sakitberturut-turut sebanyak 63, 71, 83, dan 72. 


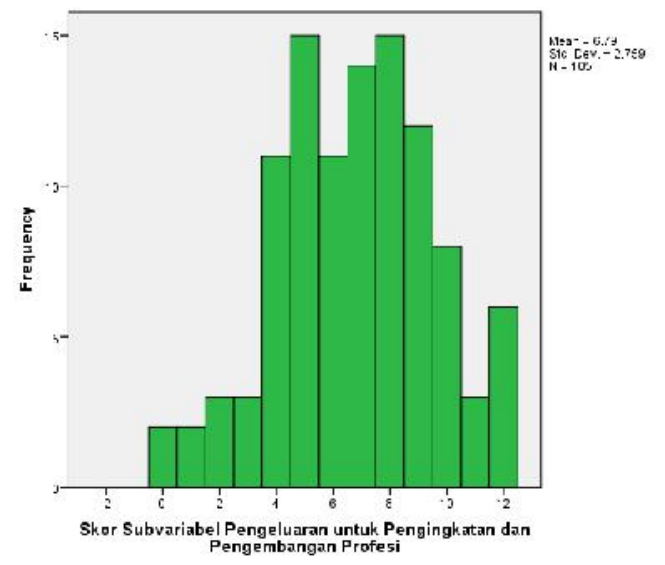

Grafik 3 : Skor Pengeluaran untuk Peningkatan dan Pengembangan Profesi Berdasarkan grafik di atas dapat diketahui bahwa skor tertinggi subvariabel pengeluaran untuk peningkatan dan pengembangan profesi skor yaitu 12 dan guru banyak menjawab pada skor 5 dan 8. Kemudian skor tersebut dikategorikan menjadi 3 yaitu 0-4 kurang baik, 5-8 cukup baik dan 9-12 baik. Distribusi frekuensi sebagai berikut :

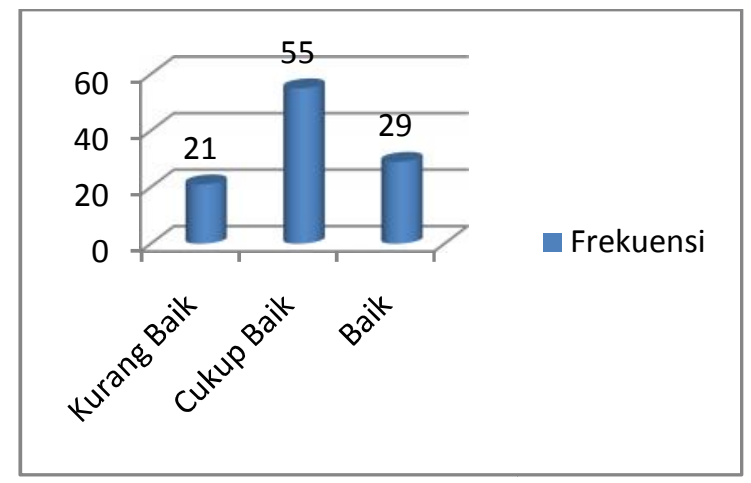

Grafik 4 : Kategori Subvariabel Pengeluaran untuk Peningkatan dan Pengembangan Profesi

Berdasarkan grafik di atas pada subvariabel pengeluaran untuk peningkatan dan pengembangan prodesi, guru-guru sudah dikatakan cukup baik dalam menggunakan tunjangan profesi pendidik sebanyak 55 orang. 


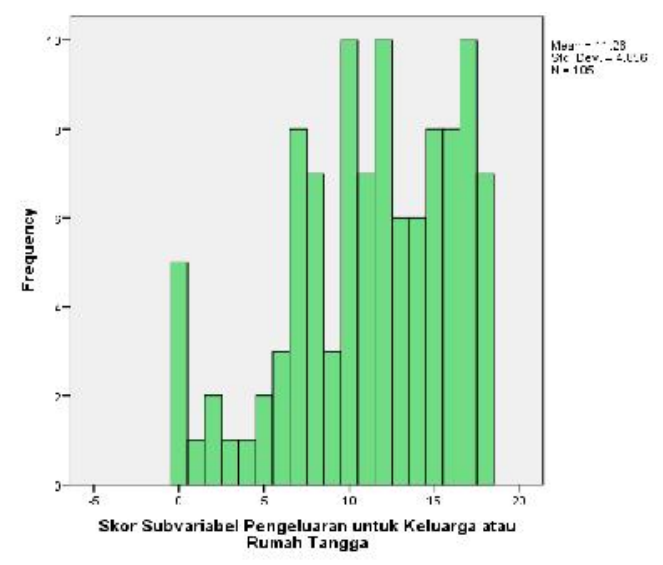

Grafik 5 : Skor Pengeluaran untuk Keluarga atau Rumah Tangga

Berdasarkan grafik di atas dapat diketahui bahwa skor tertinggi yaitu 18 dan guru banyak menjawab pada skor 17. Skor total subvariabel pengeluaran keluarga atau rumah tangga yaitu 19. Kemudian skor tersebut dikategorikan menjadi 3 yaitu 0-7 kurang baik, 8-14 cukup baik dan 15-21 baik. Distribusi frekuensi sebagai berikut :

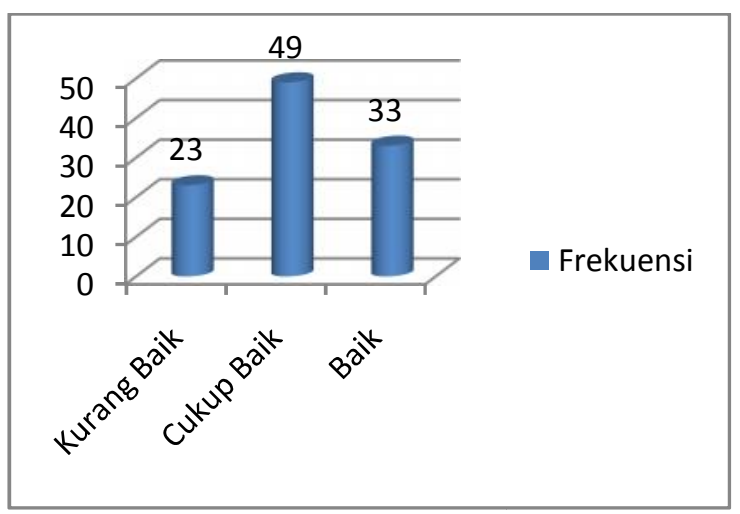

Grafik 6 : Kategori Subvariabel pengeluaran untuk Keluarga atau Rumah Tangga Berdasarkan grafik 6 di atas pada subvariabel pengeluaran untuk keluarga atau rumah tangga, guru-guru sudah dikatakan cukup baik dalam menggunakan tunjangan profesi pendidik sebanyak 49 orang. 


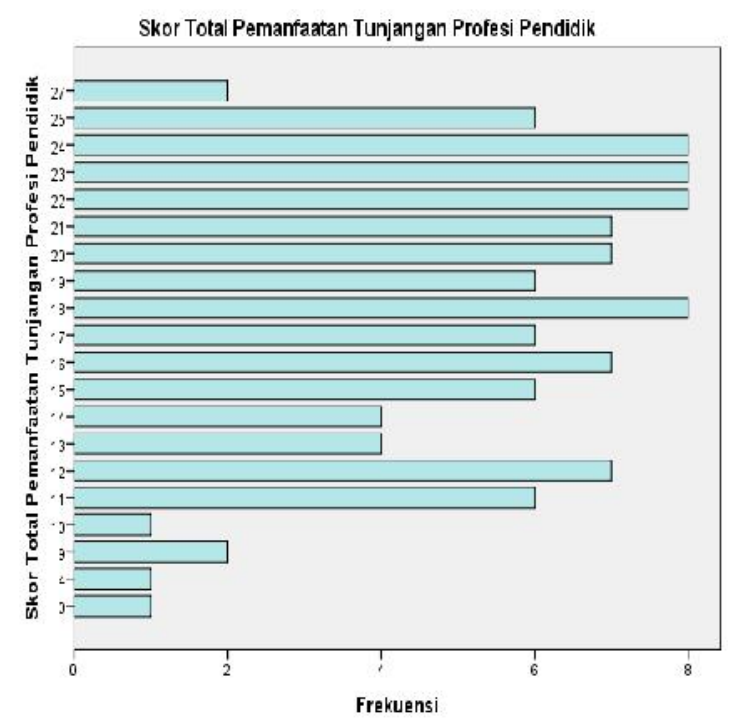

Grafik 7 : Profil Pemanfaatan Tunjangan Profesi Pendidik

Berdasarkan grafik 7 dapat dipaparkan mengenai skor pemanfaatan tunjangan profesi pendidik. Skor tertinggi dari pemanfaatan tunjangan profesi pendidik yaitu 27 dengan sebanyak 3 guru dan terendah yaitu 0 sebanyak 1 guru. Paling banyak terdapat pada skor 18, 22, 23, dan 24 sebanyak 8 guru.

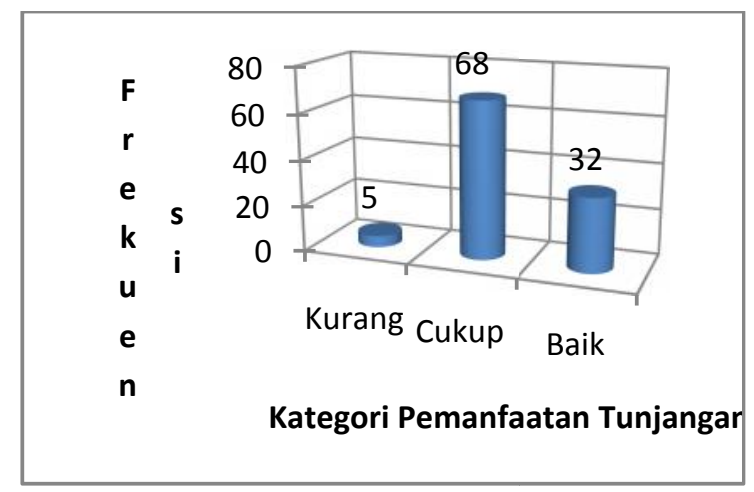

Grafik 8 : Kategori Pemanfaatan Tunjangan Profesi Pendidik

Berdasarkan grafik di atas dapat diketahui bahwa guru-guru sudah cukup baik dalam memanfaatkan tunjangan profesi pendidik sebanyak 68 orang dengan interval skor 11-21.

\section{Uji Hipotesis}

Uji hipotesis menggunakan uji beda (Independent Samples T test) atau uji t dan One Way ANOVA sebagai berikut :

Nilai thitungberdasarkan jenis kelamin sebesar 0,097 sementara $t_{\text {tabel5\% }}$ sebesar 1,983 sehingga $t_{\text {hitung }}<t_{\text {tabel5\% }}(0,097<1,983)$ dengan $\mathrm{p}>0,05$ artinya hipotesis nol yang 
berbunyi tidak terdapat perbedaan pemanfaatan tunjangan profesipendidik berdasarkan jenis kelamin diterima.

Nilai F hitung berdasarkan lama menikmati tunjangan adalah 2,202 dan siginifikan 0,116. Nilai F tabel dengan tingkat signifikan 5\% adalah 3,085 ( df1=2, df2=102). Nilai Fhitung $<F_{t 5 \%}(2,202<3,085)$ dan siginfikan $>0,05(0,116>0,05)$ sehingga $\mathrm{H}_{0}$ diterima dengan $\mathrm{p}>0,05$ artinya tidak terdapat perbedaan pemanfaatan tunjangan profesi pendidik antara lama, sedang, dan baru menikmati tunjangan profesi pendidik.

Nilai F hitung berdasarkan jumlah tanggungan adalah 2,520 dan siginifikan 0,085. Nilai $F$ tabel dengan tingkat signifikan 5\% adalah 3,085 ( df1=2, df2=102). Nilai $F_{h}<$ $\mathrm{F}_{\mathrm{t} 5 \%}(2,520<3,085)$ dan siginfikan $>0,05(0,085>0,05)$ sehingga $\mathrm{H}_{0}$ diterima dengan p $>0,05$ artinya tidak terdapat perbedaan pemanfaatan tunjangan profesi pendidik antara jumlah tanggungan banyak, sedikit, dan sedang.

Nilai F hitung berdasarkan masa kerja adalah 4,486 dan siginifikan 0,014. Nilai F tabel dengan tingkat signifikan 5\% adalah 3,085 ( df1=2, df2=102). Nilai $F_{h}<F_{t 5 \%}$ $(4,486>3,085)$ dan siginfikan $>0,05(0,014<0,05)$ sehingga $\mathrm{H}_{0}$ ditolak dengan $\mathrm{p}<$ 0,05 artinya terdapat perbedaan pemanfaatan tunjangan profesi pendidik antara masa kerja baru, sedang, dan lama.

\section{Pembahasan}

Berdasarkan grafik 2 dapat diketahui bahwa frekuensi guru yang memanfaatkan tunjangan profesi pendidik untuk belanja keinginan sebanyak 39 guru lebih sedikit daripada menabung di Bank sebanyak 63 guru. Hal tersebut sesuai menurut Sadono Sukirno (2015: 109) bahwa pada pendapatan yang tinggi rumah tangga akan menabung.

Guru berupaya melakukan kewajiban melaksanakan proses pembelajaran yang bermutu dengan membuat bahan ajar sebanyak 95 guru dan membeli buku mata pelajaran yang diampu sebanyak 92 guru. 
Guru berupaya meningkatkan kompetensi dengan cara mengikuti pelatihan sebanyak 52 guru dan berupaya meningkatan mutu pendidika dengan melakukan penelitian/PTK sebanyak 80 guru.

Sebanyak 71 guru menggunakan tunjangan profesi pendidik untuk membiayai sekolah anak. Hal ini senada dengan hasil penelitian oleh Arini dkk yang menjelaskan bahwa pengeluaran bukan makanan untuk biaya pendidikan.

\section{Kesimpulan}

Berdasarkan data yang diperoleh dari responden dan hasil analisis yang telah dilakukan, maka dapat ditarik kesimpulan guru-guru SMA di Kota Banjarmasin dapat dikategorikan cukup baik dalam memanfaatan tunjangan profesi pendidik dengan rentang skor 11 - 21 sebanyak 68 guru atau 64,8\%. Selain itu, pada kategori kurang baik dan baik berturut-turut sebanyak 5 guru $(4,8 \%)$ dan 3 guru atau (30,5\%). Diketahui juga gambaran pemanfaatan tunjangan profesi pendidik untuk peningkatan dan pengembangan profesi sebanyak 95 guru membuat bahan ajar. Sedangkan gambaran pemanfaatan tunjangan profesi pendidik untuk pengeluaran keluarga atau rumah tangga lebih banyak digunakan untuk perihal sosial yaitu sedekah dan memberi uang pada orang sakit sebanyak 84 dan 72 guru.

Hasil uji hipotesis yaitu uji beda menunjukan bahwa tidak terdapat perbedaan pemanfaatan tunjangan profesi pendidik berdasarkan jenis kelamin, lama menikmati tunjangan profesi pendidik, dan jumlah tanggungan. Akan tetapi, terdapat perbedaan pemanfaatan tunjangan profesi pendidik berdasarkan masa kerja.

\section{Saran}

Saran bagi guru yaitu diharapkan agar guru lebih baik lagi dalam mengalokasikan tunjangan profesi pendidik untuk peningkatan mutu pendidikan. Selain itu, bagi peneliti selanjutnya adanya penelitian lebih lanjut dengan menambah variabel lainnya yang dapat mempengaruhi pemanfaatan tunjangan profesi pendidik seperti usia guru dan mata pelajaran yang diampu. 


\section{DAFTAR PUSTAKA}

Admono Dwi, et al. 2013. Pedoman Penulisan Karya Ilmiah. Malang : Intimedia (Intrans Publishing Group).

Ansori, Arief, dan Sukirno. 2017. "Profesionalisme Guru Akuntansi Pasca Sertifikasi". Jurnal Pendidikan Ekonomi dan Bisnis (JPEB). Volume 5 Nomor 1 Maret 2017. Halaman 107-126

Arikunto, Suharsimi. 2003. Manajemen Penelitian. (Cetakan ke-6). Jakarta : PT Rineka Cipta.

Dewi, Astrie. (2016). Tema : 7 Pos Pengeluaran dalam Keuangan Keluarga. [Online]. Tersedia : http://duitologi.com/articles/2016/03/10/tema-7-pos-pengeluarandalam-keuangan-keluarga/ [5 Agustus 2017]

Diana, Ilfi Nur. 2012. Hadis-Hadis Ekonomi. (Cetakan ke-3). Malang : UIN Maliki Press.

Eriyanto. 2007. Teknik Sampling Analisis Opini Publik. Yogyakarta : Lkis

Kariadinata, Rahayu. Dan Abdurahman, Maman. 2015. Dasar-Dasar Statistika Pendidikan. (Cetakan kedua). Bandung : Pustaka Setia.

Kemendikbud. 2016. Petunjuk Teknis Penyaluran Tunjangan Profesi Guru SD/SLB dan SMP/SMPLB Melalui Direktorat Pembinaan Guru Pendidikan Dasar. Jakarta : Kementerian Pendidikan dan Kebudayaan, Direktorat Jenderal Guru dan Tenaga Kependidikan.

Kementerian Pendidikan dan Kebudayaan. Sekolah Kita. [Online]. Tersedia : http:/ / sekolah.data.kemdikbud.go.id/ [26 Juli 2017]

Kunandar. 2011. Guru Profesional Implementasi Kurikulum Tingkat Satuan Pendidikan (KTSP) dan Sukses dalam Sertifikasi Guru. (Edisi Revisi-7). Jakarta : Rajawali Pers.

Mangkunegara, Anwar Prabu. 2009. Perilaku Konsumen. Bandung : PT Refika Aditama.

Mulyasa, E. 2013. Uji Kompetensi dan Penilaian Guru. Bandung : PT Remaja Rosdakarya.

Narimawati, Umi dan Munandar, Dadang. 2008. Teknik Sampling : Teori dan Praktik dengan Menggunakan SPSS 15. Yogyakarta : Gava Media.

Peraturan Menteri Pendidikan Nasional Republik Indonesia Nomor 18 Tahun 2007 tentang Sertifikasi bagi Guru dalam Jabatan.

Peraturan Pemerintah Republik Indonesia Nomor 41 Tahun 2009 tentang Tunjangan Profesi Guru dan Dosen, Tunjangan Khusus Guru dan Dosen, Serta Tunjangan Kehormatan Profesor. 
Priyatno, Duwi. 2010. Teknik Mudah dan Cepat Melakukan Analisis Data Penelitian dengan SPSS dan Tanya Jawab Ujian Pendadaran. Yogyakarta : Gava Media.

Putong, Iskandar. 2015. Teori Ekonomi Mikro : Konvensional dan Syariah. Diakses 12 Desember 2017, dari Google Book.

Riduwan, M. B. A. 2013. Metode dan Teknik Menyusun Proposal Penelitian. (Cetakan ke5). Bandung : Alfabeta.

Sagala, Syaiful. 2013. Kemampuan Profesional Guru dan Tenaga Kependidikan. (Cetakan ke-4). Bandung : Alfabeta.

Sektor Pembangunan Manusia. 2012. Sertifikasi Guru di Indonesia : Peningkatan Pendapatan atau Cara untuk Meningkatkan Pembelajaran?. Jakarta : Kantor Bank Dunia.

Setiadi, Nugroho J. 2015. Perilaku Konsumen : Perspektif Kontemporer pada Motif, Tujuan, dan Keingingan Manusia. (Edisi Revisi, Cetakan ke-6). Jakarta : Prenadamedia Group.

Solomon, Michael R. 2015. Consumer Behavior Buying, having, dan Being. (Eleventh ed). The United States of America : Pearson Education.

Sugiyono. 2016. Memahami Penelitian Kualitatif. Bandung : Alfabeta.

Sukirno, Sardono. 2013. Mikroekonomi Teori Pengantar. (Edisi 3, Cetakan ke-28). Jakarta : Rajawali Pers.

Sukirno, Sardono. 2015. Makroekonomi Teori Pengantar. (Edisi 3, Cetakan ke-23). Jakarta : Rajawali Pers.

Suprihatiningrum, Jamil. 2013. Guru Profesional : Pedoman Kinerja, Kualifikasi, dan Kompetensi Guru. Jogjakarta : Ar-Ruzz Media.

Suryani dan Hendryadi. 2015. Metode Riset Kuantitatif dan Aplikasinya Pada Penelitian Bidang Manajemen dan Ekonomi Islam. Jakarta : Prenadamedia Group.

Undang-Undang Republik Indonesia Nomor 14 Tahun 2005 tentang Guru dan Dosen. 